\title{
College Librarians and the Higher Learning
}

$\mathrm{P}$ ROFessor Jacques Barzun recently put librarians in their place. $^{1}$ As a basis for developing his theme, he set up certain criteria of "attention" and "general knowledge" to measure the librarian's effectiveness. But what Professor Barzun politely said seemed to add up to this: $\mathrm{Li}$ brarians are not sufficiently informed to be at ease in the presence of scholars and other well-informed customers; they do not make critical distinctions as nicely as scholars do; and they do not as a group possess that body of traditional learning-promoted so effectively in The Teacher in Americawhich is necessary for admittance into Barzun's inner circle. . In a word, the professor is unwilling to deal with us as intellectual equals.

Now, if it were not for the core of truth the speaker had presented, any librarian present might have resented his approach. But our professional brethren merely asked Professor Barzun how librarians could more effectively serve college teachers in their work. It were as if college librarians did not normally exhaust themselves in setting things up right for the teaching program as well as in helping students complete the teaching process only started in most classrooms. Librarians, of course, could do more and better; but that would not get them into Barzun's heaven. They would only be revealing more "scaffolding;" they would not be building the true edifice whose

\footnotetext{
${ }^{1}$ Barzun, Jacques. "The Scholar Looks at the Library." College and Research Libraries 7:113-17, April 1946.
}

architects reap their rewards in terms of professional recognition and salary.

Nor did we have to wait for a professional get-together to become aware of our difficulties. We have discussed them frequently in private conversation and in conference jam sessions. From time to time our group frustration has articulated itself in professional literature. Some of the bibliography of these outcries is discussed by William Dosite Postell. ${ }^{2}$ His list of titles reveals an obviously felt need of selfimprovement, if not self-justification, of librarians as scholars, authors, and teachers. And doesn't A. F. Kuhlman's "Can the Association of College and Reference Libraries Achieve Professional Status?"3 try to resolve our evident but unwarranted inferiority complex? Add also to the recent literature Robert Bingham Downs's "Academic Status for University Librarians-a New Approach." 4

Much of this literature of complaint speaks of the good old days when scholars became librarians so that, naturally enough, librarians were scholars. If one were to try to place his finger on the transitional process which changed all this, he would probably summarize his findings in somewhat this fashion: The college and university have widened their scope, increased their student bodies, and changed their methods of teaching in such a way as to

2 "The Art of Librarianship." School and Society 6I:419-2I, June $30,1945$.

${ }_{3}$ College and Research Libraries 7:145-51, April 1946.

4 College and Research Libraries 7:6-9, 26, January 1946. 
draw in libraries on a grand scale. The magnitude of the librarian's task in this newly expanded service institution has acted to bring down the level of his intellectual productivity.

A chief goal in all of this thinking about librarians and scholars is, if we state it candidly, to achieve the salary levels, opportunities for advancement, and other privileges of our colleagues on the teaching staff. We do not seem to be getting anywhere- except for a limited number of top ranking librarians-by our scaffolding activities however brilliantly and professionally these are performed. Are we then the hopeless victims of a system or situation? We need not be.

Something of a solution must develop if we proceed on a practical, systematic basis toward the attainment of our goal. There are two basic aspects of such a programits ideological content and the specific organizational forms of activity to be undertaken. Operations in this second area will involve such decisions as: Are trade union forms more or less effective than professional organizations? In dealing with these specific aims, should we join teachers' organizations in preference to librarians' organizations, or vice versa? These and all sorts of questions of tactics and approach are best answered by experience and should be left in tentative form for the present.

\section{Successful Patterns}

We do, however, have a few specific notions as to successful patterns among the ideas we have to handle. We know, for instance, that top administrative positions are most likely to be rewarded justly. This may be accepted at face value as being well and good for those who are fortunate enough to climb into the limited number of available posts; that is, provided this par- ticular opportunity for advancement is offered with strict adherence to the competitive principle. Full publicity of openings will help in this direction. Hierarchic controls of key posts should cease to exist.

From the point of view of professional welfare, one qualification beyond all others is required of the administrator who is chosen for one of these posts. This first essential is the willingness and capacity to arrange librarianship so as to move toward the full development and self-realization of that large mass of professional assistants who, for reasons which need not be enumerated here, will never reach the very top. This administrator must, and he often has it within his power to, see to it that library jobs are not crowded with technical and clerical detail. He must relieve his assistants of every possible task which could be performed by nonlibrarian staff.

With his basic organizational structure thus rationalized, this administrator must now proceed to encourage his staff in directions which will be recognized as architecture rather than scaffolding. As a beginning he and his administrative lieutenants must renounce the too-prevalent practice of discouraging all reading during working hours. Nor should he assign to each assistant just a little more work than he can accomplish in the time allotted. No profession can possibly remain alert under such restrictive conditions as prevail in most libraries. To this may be added a liberalized interpretation of work schedules, summer vacations and leaves with pay, and part of the college teacher's advantageous modus operandi et vivendi begins to come into view. Professor Barzun sensed the unfortunate plight of librarians in the matter of free time rather precisely when he said, "It seems to me that it behooves the profession as a whole to make this representation to the authorities and provide oppor- 
tunities for librarians to read, to become well-informed, and to serve their public in that intangible, yet important, way of being the same kind of person."

Now, having to an extent thus liberated his staff members, the administrator should be capable of channeling their energies so as to provide optimum conditions for creative librarianship. One of the chief objectives of a college library organization should be to arrange for professional librarians to work under conditions conducive to the manufacture of a product comparable to that of their colleagues, the college teachers. There is no doubt that, by and large, college librarians would, if given the chance, compete successfully with college teachers for available rewards. And who will deny that the cause of education, from the standpoint of student, teacher, and librarian, will be favored by this emphasis.

\section{Ways to Reach Goal}

To date we see three broad types of endeavor which may lead college librarians toward the status they desire. Subsumed within the first is such a group of professional activities as A. F. Kuhlman lists in. the article mentioned above. The items which at the moment seem best suited to accomplish immediate aims are: "Improve the professional education and training for college and reference librarians. Develop strong professional leadership in A.C.R.L. membership. Integrate A.C.R.L. librarianship with instructional and research efforts of faculties and learned societies. Encourage experimentation, research, and publication on problems of librarianship in college and reference libraries." Just how these activities will enhance professional status in the desired manner is seen only vaguely now. But as the elements of Kuhlman's program are worked out, their promise will be realized at least in part.
Whatever else we may do in developing this part of our program, we must point out in no uncertain terms that our instructional and research activities in the field of librarianship bear marks of academic achievement comparable to that of the teaching staff. We certainly should be able to demonstrate that the operational level reached by technical process librarians in the organization of knowledge and the materials of learning requires a kind of preparation and ability generally expected of college teachers. Similarly, the educational attainments and direct teaching functions of reference and research librarians should promote the process of professional aggrandizement. If we find it difficult to sell these ideas on the basis of present library organization, we must reorganize our libraries.

The second kind of tactical endeavor and its already fruitful results are strongly implied in R. B. Downs's article. Professional librarians must spend some or all of their time in the college classroom. The librarian and his staff must promote a full program of instruction in the use of library materials.

The third suggestion to be offered here is the creation of a large number of highranking positions for subject specialists. The old debate about librarian versus specialist is not of consequence in the attempt to advance status. Whatever library assistants start as, they should be encouraged and assisted along lines of specialization. This may occasion further reorganization of professional schools of librarianship, and there are hopeful signs in this direction. Certainly librarians who have this type of emphasis in their professional preparation are less likely to stand in awe of their colleagues on the teaching staff. Moreover, the program of subject specialization must not suddenly be brought to a close upon 
promotion to an administrative post. Every possible effort and device must be used to permit librarians of all ranks and in all positions to develop as rapidly and as fully as their professorial colleagues.

\section{Scholarship in Profession}

There is a significant lesson to be learned from our observation of whence arises the bulk of solid scholarship and professional research in the field of librarianship. It comes from librarians who have left their positions for a year or two to engage in graduate study and research; it comes from instructors in library schools; it comes from professional leaders who have managed to liberate themselves from the administrative details of their work and perhaps have been able to command the assistance of a staff member or two in their productive research ; it comes from that small group of inexhaustibles whom no vocational load could prevent from doing sustained intellectual work.

If all else is agreed upon, then let us deliberately devote our efforts to the solu- tion of the problem of staffing and division of labor. Perhaps we are planning services beyond what our colleges think they need and are willing to pay for. A little service contraction may bring the point more forcefully to college administrators. By maintaining myriads of departmental libraries, fraternity and dormitory libraries, browsing rooms, and instructors' working collections, we earn the same kind of condescending gratitude that faithful servants receive from their employers. When we run reserve reading rooms with the smoothness of a well-oiled machine, our clerical efficiency rating rises. These are but examples of our activities which, desirable as they are, earn for us the dubious distinction of being "such accommodating people."

Self-preservation may demand depriving our college teachers of some of the comforts to which we have been accustoming them. They have been taking all of these luxuries for granted and have recognized them as mere scaffolding. Perhaps they need the experience of trying to paint a high ceiling without a scaffold.

\section{The Future of the Catalog}

\section{(Continued from page 22)}

ing cost. If savings are to be effected, they cannot be effected at the expense of subject approach. The situation may change if and when more, and more adequate, subject indexes, bibliographies, and abstracts are regularly published.

All that has been said tends to stress the increasing importance of the cataloger in the research library of the future. It is evident that much more analytical skill and subject background will be required of him than is now the case. Furthermore, he will have to be not only thoroughly acquainted with the fields of specialiżation of his own library but it will also be part of his work to watch out for any possible trends and changes of point of view in related fields. As a first intermediary between the incoming material and the scholar, the cataloger is no less concerned with the service aspects of the library than the reference librarian. $\mathrm{He}$ should be at all times informed of the research needs and new fields of interest of the library's clientele, and his outlook and habits of thought should approximate as closely as possible those of the research scholar. And when the cataloger is able to do all these things, and successfully, the difference between his profession and that of the research scholar will be one in name only. 